\title{
ARTICLES
}

\section{Bor Forced Labor Service as Reflected in Diaries}

\author{
Tamás Csapody \\ Semmelweis University \\ csapody.tamas@med.semmelweis-univ.bu
}

Military forced labor service was introduced in Hungary during World War II. Men who were unreliable from the aspects of origin, religion, nationality or politics were conscripted for forced labor. Initially, forced laborers constructed primarily military objects on the home front, while later they were also dispatched to the battlefield. They had no weapons or uniforms, their provisions were poor and often they had to do building or mine clearing in the most dangerous areas. Hungary sent a total of approximately 6,000 forced laborers to work in the southern operational territories in 1943 and 1944. They had to undertake forced labor in the mining district of Bor in Yugoslavia, which was under German occupation. The majority were Jews, but there were also Jehovah's Witnesses, Reform Adventists and Nazarenes. They lived under Hungarian military supervision and worked under German management. The locations of forced labor, the durations of time spent in the mining district, the experienced sufferings, etc. were very different. The forced laborers themselves were also different, for example with regard to their origins, occupations, and age. Several Jewish forced laborers wrote diaries and some of them managed to take those home. Later diaries written in Bor had a particular fate. Some were lost for a time or have remained in fragments, while others with important additions were deposited in archives or taken abroad by the diarists. All the diaries analyzed in the study testify to the survival of their writers. However, they mostly bear witness to the everyday life of forced labor service in Bor (otherwise difficult to learn about) and the behavior of those who held them, as well as the forced laborers' sufferings, faith and hope. At the same time, they speak about the entirety of forced labor in Bor alongside its personal stories. The diaries are ego-documents, yet also historical sources. Their factual descriptions and subjective approaches augment our knowledge gained in the past. The six diaries written in Bor and analyzed in this study are personal confessions with significant source value.

Keywords: World War II, forced labor, Jews, diaries, Hungary, Yugoslavia, Bor, Holocaust, ego-documents

Diaries written in Bor occupy a special place in the history of the Bor forced labor service. They were written during World War II, but they cannot be classified as typical war diaries. True, they were not written in the hell of war, during a retreat or on the home front. Yet they were still penned under conditions of war, confined 
between fronts, in theaters of military operations, far from the Hungarian border, in a foreign land, and often also under infernal circumstances. Although those who wrote the Bor diaries in forced labor service were subordinated to the Hungarian and German military, their diaries cannot be regarded as soldiers' diaries or work diaries, even though they contain descriptions of places of work.

It was not prisoners treated as prisoners of war but forced laborers in captivity who wrote the diaries in secret. Although most of the diaries contain descriptions of journeys and the texts also record forced and frequent changes of place, they naturally cannot be called travel diaries. Though the fear of destruction appears repeatedly in the descriptions, since the shadow of death was present in the diarists' lives due to accidents at work, illnesses, beatings, murders, and executions, they cannot be regarded as camp diaries written in concentration or extermination camps. In truth, we can say that they were written by victims of the Holocaust in forced labor camps. ${ }^{1}$ They simultaneously represent letter, camp, prisoner, and travel diaries. The Bor diaries found during my research are ego-documents written by Jewish forced laborers, more or less regularly and chronologically recorded, which are fragmented and which contain personal notes. ${ }^{2}$

\section{The Known Bor Diaries}

At present, we have knowledge of six diaries that were written at least partly in Bor. ${ }^{3}$ Of the six, only four can be appropriately described, since two have survived only in fragments. Those two have more content missing than what exists (László Faludi) or what can be accessed at present (György Szöllösi). The content that is known of them deserves far more than just a mention, yet it is clearly insufficient to allow a comparison with the four that can be read in their entirety (the diaries of György Laufer, Imre Pártos, Béla Somló, and Lajos György).

1 The roughly 6,000 Hungarian forced laborers in total taken to Bor in Serbia in 1943 and 1944 included 161 Jehovah's Witnesses, 19 Reform Adventists, and 9 Nazarenes. We do not know if any member of the minor congregations kept a diary.

2 On the diary as a historical source, see Gyáni, "A napló mint társadalomtörténeti forrás: A közhivatalnok identitása," 145-60.

3 The chronological framework of the study extends from the draft for forced labor service to the individual's return to his permanent residence. There are several memoirs which are regarded as Bor diaries by posterity. See, for example, Károly Koltai's memoir, which according to the official records of the Holocaust Memorial Centre is a "hand-written diary and memoir." Holocaust Memorial Centre 2011.360.1. 
The diaries cover durations of varying lengths. Information about the callup for forced labor service in Bor is the earliest initial point of time (May 31, 1943), while arrival at the authors' place of birth in Hungary and accounts of subsequent experiences mark the latest (April 3, 1945). However, the diaries were written over very different time spans between the two time limits. Time frames are defined essentially by "external" circumstances, such as who was called up for forced labor service in Bor, when (1943 or 1944), and which group (the first or second "stage") the person left Bor as part of. "Internal," subjective differences also played a role in terms of from when and until when the diaries were written. Differences defined as "internal" and "external" were naturally closely connected, since, for example, the forced marches and mass murders which were common during the first stage made it impossible to record the events. This was very different from the situation of those who were dispatched from Bor in the second stage and had plenty of opportunity to write diaries in the period following liberation after they arrived in Temesvár (Timişoara) or Szeged, which both represented freedom and calm for them.

Three of the Bor diaries are held in public collections, while I was able to study or was informed about the other three from contacts of former Bor forced laborers or their descendants. All of the diaries, except for one, are unpublished.

\section{Lász̧ló Faludis Diary}

One of the two diaries that cannot be studied in full was written by László Faludi. ${ }^{4}$ His hand-written diary is of unknown length. ${ }^{5}$ However, the existing numbered eight pages suggest that its length must have been some 100 pages. His notes written in a grey pen on lined pages are clearly legible.

László Faludi, whose permanent residence was in Budapest, was a forced laborer in Páhi. From there, his unit was ordered to Szeged and then to Bor. According to his diary, the steamer which transported them to Serbia was sailing

4 László Faludi (mother's name: Sarolta Fingerhút; Budapest, December 19, 1920-Budapest, after 1980). Unit V/4. Special labor unit V. supplementary battalion; identification number: 3006.20.3432. Skilled textile mill worker in Budapest.

5 Diary of a Bor forced laborer. MNM, Collection of Contemporary Documents 83.242.1. Pages 29-32 and $81-84$ of the diary survived. Parts of the diary were displayed at the exhibition held in the Hungarian pavilion of the Auschwitz-Birkenau State Museum in 1979. Three camp postcards written from Bor, which László Faludi wrote to his parents and siblings in Budapest, and one sent to Bor, which he received from his mother, also exist. MNM, Department of Historical Photographs, 78.386.1-4. 
between Titel and Belgrade along the Danube on July 14, 1943. ${ }^{6}$ They reached Belgrade at night, after having experienced a huge storm lasting an hour. The following day, they reached their destination, the port of Prahovo on the Serbian side of the Serbian-Romanian border along the Danube. The journey by rail to Zaječar and then to Bor took two days. The 3,000 forced laborers arrived in Bor on July 17 . He was held captive in Bor in the camp called Berlin for exactly 14 months to the day, until September 17, 1944.

The accessible (presumably) one tenth of the diary suggests that he wrote about three major themes: the forced labor in Bor, the past labor movement and the communist future, and his personal life. Employing the diary genre, Faludi wrote an autobiographical memoir, which is not at all unusual in such literature. He used his diary as a memoir and as a result it has a retrospective character.

His diary is explicitly for posterity. It is addressed not only to those who might find his notes, but to "the future generation who will appreciate" his writing. Thus, for Faludi, writing a diary was an activity intended for a larger, anonymous readership rather than any specific individual or, at least according to the text, the author himself. It is a message for the youth of the future, written amidst the suffering of forced labor service. It is full of pathos and is ideological, almost with an overtone of propaganda.

Considering the proportions of the fragmented diary, the largest section is a description of the past labor movement. The text clearly shows that Faludi came from the organized labor movement, in which he was socialized, started to read literature, and found his best friend. He defined himself as a skilled worker in a cotton mill and a proletarian who "struggled against the infringements of capitalism" and engaged in anti-war propaganda both inside and outside the mill. He believed in "the matter of liberty, equality, brotherhood, peace, work, and bread," and his soul "was united with the souls of other proletarians." "Socialist poets" became his "soul mates" in the movement, and he mentions Endre Ady, Attila József, and Sándor Petőfi by name. Influenced by their writings, he himself began writing poems and short stories. His younger brother became his colleague in the movement, and Faludi refers to him as always being the "best

6 The steamer transporting László Faludi and its towboat departed from Szeged towards the south on the River Tisza and reached the Danube at Titel.

7 Faludi, Diary of a Bor forced labourer, 32. 
comrade and brother." ${ }^{\prime 8}$ Faludi also recounted two experiences of key importance connected to the labor movement: reading something ${ }^{9}$ and May 1, 1938.

Faludi was sent back from Bor in the first group, and he must have escaped somewhere on the way while still in the Serbian mountains. He joined Tito's partisans. ${ }^{10}$

Nothing more could be found about László Faludi in Hungarian archives, and only tiny bits of information were accessible in online data bases. His brief letters were usually published in the letters section of dailies and weeklies. They suggest that he remained on the left and maintained his critical attitude and sensitivities in terms of public life and his positive vision of the future. ${ }^{11}$

\section{György Szöllösi’s Diary}

The author of the other Bor diary that cannot be read in full is György Szöllösi. ${ }^{12}$ His hand-written diary exists in full, yet it cannot be accessed at present. Neither the few pages at my disposal nor the diary extract sent by György Szöllösi’s $\operatorname{son}^{13}$ provide sufficient information to analyze the diary. ${ }^{14}$ However, Szöllösi’s life and, within it, the period of forced labor service in Bor can be reconstructed on the basis of a video interview recorded by the USC Shoah Foundation Visual History $^{15}$ and his testimony in one of the trials held by the people's tribunal. ${ }^{16}$ Although it is impossible to get closer to the notes in the Bor diary, we still

8 Ibid., 83.

9 He was reading Upton Beall's Kutató Sámuel.

10 László Faludi handed over two certificates made out in the Serbian and Croatian language by the Yugoslav partisans to the Museum of the Hungarian Labor Movement (MMM), a legal predecessor to MNM. Acknowledgement of receipt: none. Budapest, October 4, 1978. The certificates cannot be found at present.

11 His brief contributions were published in Népszabadság and Új Tükör between 1976 and 1980.

12 György Szöllösi (George Brent) (mother’s name Mária Weisz; Zilah, April 2, 1926-Dallas, January 24, 2001) was a violinist, assistant policeman, member of the French Foreign Legion, and businessman.

13 Dennis Brent (mother's name Anita Myerson; Houston ?-December 1950) was a writer, retired editor, producer living in Dallas.

14 In addition to the cover, I was able to see only four poorly scanned pages of the diary. The school exercise book with a checkered cover and pages could be a total of approximately 30-40 pages. Dennis Brent's email to Tamás Csapody. Dallas, August 24, 2006. (For years, I asked Dennis Brent to show me the full diary, but in vain.)

15 VHA USC, George Brent, interview 19753, 1996.

16 MNL CSML, Nb.206/1945, János Császár's trial at the people's tribunal. Record of testimony. Acknowledgement of receipt: none. Sopron, June 7, 1945. 36-38. Records. No. of acknowledgement of receipt: Nb.206/1945.17. July 30, 1945. 49-50. 
learn that Szöllösi was taken to the Bregenz subcamp in the spring of 1944. In the one and a half months he spent there, he experienced instances of "tying" (being hung from his hands after they had been tied together behind his back) ordered by the military detachment, and he witnessed the mutilation of two of his fellow laborers following their unsuccessful attempt to escape. Later, Szöllösi was ordered to work in the mines from a railway construction, and thus he ended up in the Straflager (punishment camp) in Bor. Here, he did not live under the supervision of the Hungarian military but rather of German soldiers. Since he did not get there as a form of punishment, he was far better off than he had been in the Bregenz subcamp. In the end, he was sent home as part of the second group.

Tito's partisans liberated him on September 30, 1944. Like many of his fellow forced laborers, he first went to Temesvár and then to Budapest, which had been liberated in the meantime. (Subsequently, he probably wrote his diary from spring 1943 to the beginning of 1945.) Following his return home, he became an assistant police inspector in Sopron in the summer of 1945. After spending a short time in Germany and France, he left for the United States in May 1947. He settled in Chicago, changed his name to George Brent, and became a businessman.

\section{György Laufer's Diary ${ }^{17}$}

At present there are four Bor diaries which can be accessed in full. The first note in György Laufer's ${ }^{18}$ 36-page hand-written diary, which is now part of a public collection, ${ }^{19}$ was written more than two and a half months after his arrival in Bor on October 5, 1943. His last note was recorded ten days before the first group left Bor on September 7, 1944. So the diary starts "too late" and finishes "too early," including a duration of almost 11 months to the day: a large proportion of the nearly 14 months he spent as a forced laborer in Bor. With regard to its total length and the number of entries, the diary can be described as "brief." Laufer wrote his diary continuously, but not daily. The longest gap, which lasted nearly

17 The diary was published in full. Csapody, "Laufer György naplója," 184-224.

18 Laufer, György (mother's name Róza Somogyi; Budapest, August 9, 1920-Budapest, September 30, 1995). Unit V/4. Special labor unit V supplementary battalion. Identification No. 3009.20.2796. He was a photographer, press worker, motorcycle delivery man, leather goods artisan, and self-employed plastics craftsman.

19 Hungarian Jewish Museum and Archives, B/327 L2_E4_75. Documents Collection connected to the Holocaust, Laufer György Diary written during Bor forced labor service. 
two months, occurred between January and March, 1944. It was presumably cause by an illness which lasted for five weeks. Like László Faludi, Laufer was in the Berlin camp, and he also worked in the limestone quarry in the village of Krivelj to the north, as well as in Bor, but in Bor, he worked as a photographer.

His diary touches on the series of changes which occurred in the life of the Berlin camp beginning in early 1944 . When the new chief commander of the camp, lieutenant colonel Ede Marányi, ${ }^{20}$ arrived in this period, the life of forced laborers changed dramatically. As Laufer noted in his diary, prisoners were treated more and more strictly. Individual and group "tying" took place regularly and frequently, and as a result, more and more people tried to escape. From his notes, it is possible to reconstruct precisely to the day the time when 15 "lads" fled on March 27, 1944. More people were able to flee within a few days. Of those who tried to escape, 10 were captured the same week. Ede Marányi had two of them executed on Sunday, April 2, 1944. In his diary, Laufer reported the death of a "Jehovah's Witness" escapee (April 11, 1944). Although he does not mention names, the dates of the deaths agree with the data in the official records of military graves. ${ }^{21}$ However, the attempts to escape were motivated not only by the increasingly common practice of "tying," but also by other forms of abuse. Laufer noted that from the beginning of April 1944, prisoners were only allowed to receive letters from their parents or wives, but not from girlfriends.

György Laufer identifies August 29, 1944 as "the most exciting and eventful" day of the time he spent in Bor. This was because, as he writes, "we were called upon to be ready to march because we could expect the order to set off at any moment." 22 The following days were spent waiting, although Laufer had only recently ended up in Bor as a photographer. A one-line note in his diary was made at 4:50 a.m. on September 7, 1944 saying, "Alert! My God be with me."23

20 Marányi, Ede (mother’s name Katalin Dörgő; Pétervárad, October 7, 1896-Markdorf, Germany, September 20, 1985). His fictitious data: Antal Fehér, Komárom, March 5, 1900 was a special corps lieutenant colonel, off-duty Arrow Cross Party colonel, and commander of the camp group in Bor.

21 The two executed forced laborers were Sándor Friedmann (Budapest, 1907-Bor, April 2, 1944), Special Labor Unit battalion V. Resident of Budapest, and Tibor Béla, about whom there is no data in the official records of military graves. The Jehovah’s Witness was István Besenyei [András Besenyei] (mother’s name Borbála Nagy; Kisléta, November 28, 1911-Bor, April 11, 1944), special labor unit 801. According to the file of official records of losses, he "died during a collapse of earth." HM HIM Records of Military Graves, search by name: http://www.hadisir.hu/hadisir-nyilvantarto (last accessed September 21, 2018).

22 Laufer, Diary, August 29, 1944.

23 Laufer, Diary, July 9, 1944. 
However, the alert was not followed by marching orders at that time. He had to wait another ten days, though there is no record of this in his diary.

The diary comes to an end here, but Laufer's story in Bor, of course, continued. He was dispatched from Bor in the first phase. He did not write his diary during the marches. He was shot in the head in Cservenka (Crvenka/ Tscherwenka) in western Bačka or its vicinity, but shockingly, he survived, and after he had recovered, he returned to Budapest in April 1945. ${ }^{24}$ The effects of György Laufer's severe head injury inflicted in the vicinity of Cservenka accompanied him throughout his life.

Little is known of the photographer György Laufer who finally settled down in Budapest and started a family after his years in Szeged. Taking the circumstances of the period into account, the fact that his name is included in the list of profiteers published in the Bulletin of the People's Tribunals in its issue of March 1946 does not tell us anything about him. ${ }^{25}$ He became an active member of the Bor group, and his name appeared in the documents of secret investigations in connection with the death of Miklós Radnóti (1967-1975). ${ }^{26}$

\section{Imre Pártos's Diary ${ }^{27}$}

Law graduate Imre Pártos and economist Béla Somló belonged to the older generation among the Bor forced laborers. Pártos was 42 years old and Somló was 41 when they reached Bor in 1943. They were taken to Bor in the same group as the much younger György Szöllösi and Lajos György, who also wrote diaries. Pártos and Szöllösi presumably knew each other, since they were taken to the same subcamp.

From the day of joining his unit (June 5, 1944), Imre Pártos recorded something in his diary every day up to the last day of the year. He wrote entries in his diary for a total of 210 days, regardless of which Bor camp he was in or which way he had to take after liberation. He spent four months in Bor camps

24 BFL, Nb.3281/1945.80. Trial of cadet sergeant András Tálas at the people's tribunal. György Laufer's testimony. Budapest, October 30, 1946. No. of acknowledgement of receipt: 619/1946.

25 Anonymous, "Itt a feketézők, valutázók, árdrágítók második hivatalos listája," 5.

26 ÁBTL, 3.1.5.-16476. File codenamed Abda murderers. The appearance does not have any significance since György Laufer did not go with the marchers after Cservenka.

27 Dr. Imre Pártos (mother's name Malvin Freidlander; Budapest, March 27, 1902-Budapest, September $30,1973)$ was a solicitor, people's prosecutor, deputy people's prosecutor, deputy chief prosecutor, and legal counsellor. 
and two months wandering, marching, and fleeing between Bor and Szeged. He then spent two months in the liberated city of Szeged.

He generally summed up the events of a given day in three concise sentences. An obvious reason for being concise was that he wrote his diary in a small notebook (the only one among the Bor diaries) which offered him only a limited amount of space. Unlike the other diarists, he did not have to do physical work. From the very beginning to the very end, he was a clerk, and he was aware that this was a privilege. He was not held in contempt for being a legally qualified clerk, and if he had anything to fear, it was only the members of the detachment outside his unit. Enjoying the trust of both the detachment and his fellow forced laborers, he became president of the "welfare committee." ${ }^{28}$ His estate $^{29}$ includes an original document that indicates an income of 10,092 pengös and expenditures of 4,469 pengós. This suggests that a self-help social support system was organized with the approval of the camp commander in the Bregenz subcamp. However, Imre Pártos was able to take home both this unique document and a possibly complete list of names (497 in all) of those in the subcamp.

Pártos and the other forced laborers alongside him were liberated by the partisans from the second group setting off from Bor. This meant that he was finally freed from Bor, yet neither had the war come to an end nor was he no longer in danger. The story of his march with the partisans and his escape from the Germans is unusual but, thanks to his diary, we know it. Pártos did not advance in the direction of Arad or Temesvár, as one would have expected, but traveled instead to Szeged via Nagybecskerek (Zrenjanin). He arrived barely two weeks after Szeged was liberated. One day, he was still threatened by the horror of public work and "malenkij robot," while the next day he was already working as a detective with the Szeged police. Although the diary provides information about the increasing workload at the police, it does not reveal details. It is also known only from a note which was written after he had stopped regularly writing in his diary that he was appointed as Szeged tribunal prosecutor on June 6, 1945. Pártos worked in both job in which he had both political and professional competencies for 16 months, until October 31, 1946, when he was relocated to Budapest.

The files of the people's tribunal and the local press provide a fragmented picture of Imre Pártos's work as a prosecutor. Newspapers in Szeged and its

28 Pártos, Diary, July 4, 1944.

29 The original diary and Imre Pártos's documents connected to his forced labor service in Bor are in the ownership of his daughter-in-law and granddaughter, who reside in Budapest. 
vicinity reported on some 35 people's tribunals for which Pártos served as prosecutor. ${ }^{30}$ During the trials, he acted as prosecutor in cases in which charges were brought against particularly important war criminals and "anti-people" criminals, such as the commander of the former ghetto of Szeged, the former chief of police, the former Lord Lieutenant, the former deputy mayor, and the former guard commander of the Csillag Prison. In several cases, Pártos was the people's prosecutor in the trials of military superiors of Jewish forced laborers. As a tribunal prosecutor he participated in at least two cases when the people's tribunal passed sentence on former detachment members in Bor. ${ }^{31}$

After almost exactly two years spent in Szeged, he was appointed to the position of people's prosecutor in Budapest (October 31, 1946) and deputy chief people's prosecutor eight months later (June 6, 1947). This took place at a time when the Communist Party was seizing power. The people's tribunals often played a role in this. Pártos represented the prosecution during certain phases of the trials of the Arrow Cross chief of press Mihály Kolosváry-Borcsa, ${ }^{32}$ minister from the Smallholders' Party Endre Mistéth, ${ }^{33}$ and social democratic leader Károly Peyer. ${ }^{34}$

After the people's tribunals ceased to function, the government appointed Pártos deputy chief state prosecutor (January 27, 1950). ${ }^{35}$ About five years later, the Presidential Council of the Hungarian People's Republic awarded him the "Order of Merit for Socialist Labor" in "recognition of his excellent work in the Chief Prosecution Office." At the time, Pártos was the prosecutor of the main department of the Chief Prosecution Office (December 24, 1954). ${ }^{36}$ Following

30 Primarily $S_{z e g e d i}$ Népszava and Délmagyarország, less frequently Szegedi Kis Újság, Makói Népíjság and Szentesi Lap published some news in connection with Imre Pártos.

31 MNL CSML, Szeged. Nb. 1200/1945. Captain István Vida’s anti-people crime. Sentence: two years imprisonment. Also: MNL CSML, Szeged. Nb. 1106/1945. Lance corporal Mihály Palócz's war crime. Sentence: ten years hard labor by the court of first instance, changed to three years by the court of second instance.

32 Dr. vitéz (“the Valliant”) Mihály Kolosváry-Borcsa (mother’s name Margit Kolosváry; Kolozsvár, June 27, 1896-Budapest, December 6, 1946) was a journalist, editor, titular state secretary, and member of parliament. BFL - XXV.2.b - 13981-1945.

33 BFL - XXV.1.a - 2815-1948, Dr. Endre Mistéth (mother's name Emília Konstantinovics; Buziásfürdő, September 10, 1912-Budapest, July 12, 2006) was a bridge construction engineer, state secretary, and minister.

34 BFL - XXV.1.a - 3757-1947, Károly Peyer (mother’s name Katalin Frank; Városlőd, May 9, 1881New York, October 25, 1956) was an ironworker and minister, member of parliament.

35 Magyar Kö̈löny, 1.

36 Magyar Közlöny, 754. 
the suppression of the 1956 revolution, he did not participate in the show trials. ${ }^{37}$ Pártos began his career as a solicitor before the war and retired as a legal counsel from the Budapest Contractors' Company on December 31, 1966.

\section{Béla Somlós Diary}

The author of the longest diary known among this admittedly small group was Dr. Béla Somló. ${ }^{38}$ The text, which exists in a typed transcript in a public collection, is several times longer than any other Bor diary. ${ }^{39}$ The manuscript is a typical example a work with a retrospective character which is not "intact," 40 since in the absence of the original hand-written diary, it cannot be established whether subsequent changes were made and what expectations the author wanted to comply with in relation to any potential changes. Béla Somló passed on to succeeding generations all of his diaries about marches into the regions of the southern borders of Hungary and to Ukraine in the same way. ${ }^{41}$ At that time, the anti-Jewish laws had not yet affected Somló, and he participated in the reinforcement of the occupying troops as a soldier of the Pécs mechanized division.

Somlós diary written in Bor is a source of abundant information about the lives of forced laborers who were taken to the Rhön subcamp in the second group. After his fortunate liberation, he provides a uniquely rich description of the colorful life in Temesvár, a city which survived the war with relatively little damage and had already been liberated. It was an urban center in which Jews, Hungarians, Romanians, and Russians lived together.

The bulky file of surveillance documents kept by the State Security Authority reveals more about Béla Somlós post-1945 life than any other source. Somló,

37 He is not included in the 1956 data base of the Committee of National Remembrance (NEB) in any form. https://perek56.hu/ords/f?p=1051:1. (Last accessed June 18, 2019.)

38 Dr. Béla Somló [Béla Schwartz] (mother’s name Körpel Ilona; Budapest, July 14, 1903-Budapest, April 2, 2000) was a chartered economist, agrarian economist, bank clerk, and photographer in Budapest.

39 HM HIM HL, PgyM/368 and M/368. His Bor diary consists of two large units. The section written in Bor consists of 49 pages. The other section, which was written in Temesvár, comes to 64 pages (Bor, June 1, 1944-Temesvár, October 19, 1944 and Temesvár, October 19, 1944-Budapest, February 27, 1945). The author later transcribed the texts for the Archives of Military History in 1979 and 1982.

40 Kunt, "Kamasztükör," 15-20.

41 HM HIM HL, PGy 2826. The participation of the Pécs motorized heavy vehicle division IV/2 in entering the region to the south of Hungary's border in 1941 (1980). Also: HM HIM HL, TGy 2811. The participation of the column of the Pécs motorized vehicle division IV/2 in the rapid deployment force of the military campaign in Russia. 
who was not a party member, spoke several languages and liked music. He was kept under surveillance on suspicion of spying for six years between 1950 and 1956. The suspicion was unfounded, and his case was closed. ${ }^{42}$

\section{Lajos György's Diary ${ }^{43}$}

The author of the sixth Bor diary which has survived in full ${ }^{44}$ is Lajos György. While I had to make inquiries about László Faludi and Béla Somló and about György Laufer's authorship, the opposite was true in the case of György. Also, he was the only person among the Bor diarists with whom I was able to meet in person. ${ }^{45}$ His son, aesthetician Péter György, first mentioned the existence of the diary in a biographical essay published in the literary journal Alfold in $2010 .^{46}$ A year later, in his essay-novel Apám belyett ${ }^{47}$ (Instead of my father), which met with considerable interest, the story of his father's forced labor service in Bor and his Bor diary played essential roles in the first seven chapters.

Lajos György's Bor diary can be divided into three distinct sections based on chronological and topographical aspects: Bor, liberation and wandering, and finally, being home in Budapest. Regarding its themes, it is a historical and a personal diary. The personal thread is intense in the sections written during his time in Bor and during the period he spent wandering and also in the notes made after he had returned home, although in the latter, the proportions are naturally turned around completely. The narrative changes from a war-time forced labor camp diary into a "travel diary" and a personal one. It is the diary of a year in the life of a young man who was 18 and then 19 years of age and who was taken to a forced labor service, compelling him to cross international borders, pass through theatres of military operations, and learn about the old and new systems from close-up, and yet György was barely able to separate from his parents. In addition, he was in love. So the text is also a diary documenting his turbulent emotional life over the course of a single year of his first love. Moreover, the

42 ÁBTL, 3.1.5. O-9054. Béla, Somló.

43 Dr. Lajos György (mother's name Emma Schwitzer; Budapest, April 16, 1926-Budapest, November 1, 2008) was a physician, editor, writer, environmentalist, ecologist, and doctor of the Hungarian Academy of Sciences.

44 The original copy of the diary is with Lajos György's widow, Otilia Vass, who resides in Budapest, while the copy seen by me is in the possession of Péter György.

45 Email communication from Lajos György to Tamás Csapody. Budapest, September 13, 2005.

46 György, "Az amnézia-terápia," 64-69.

47 György, Apám belyett, 2011. 
diary has another important layer. The text is a document which sheds light on the ways in which his attitude towards the communist idea developed via practical trials. Thus, Lajos György's diary can clearly be regarded as a diary of transformation, mobility, and the process of becoming an adult.

Lajos György wrote his diary between May 31, 1944 and April 3, 1945. The section on Bor embraces a shorter period, and it also contains entries written during and about the liberation and the events of the months after György had returned home. It begins when he was drafted to work as part of the forced labor service, and the diary contains entries kept over the course of a year, almost to the day. Over the course of this period of time, according to his entries, György slept in a total of 58 places, starting with Jászberény, the location specified in the summons he received, followed by the locations in Bor, and on the way home following liberation as far as to his residence in Budapest.

György's diary contains drawings, which is not unusual in diary literature, though his is the only one among the Bor diaries that contains drawings. Tiny sketches in red ink are found in the margins and, in some instances, at the top of the pages. They are connected to the texts. György drew a castle, rails, mine carts, piles of bricks, a red star (with "Long Live Tito" underneath in Serbian), a hammer and sickle, a red cross, tanks, books, a watch (with the word "watch" in Russian underneath), a Christmas tree, and a traditional Hungarian Christmas cake. ${ }^{48}$ In the same red ink, he underlined titles, sub-titles, some dates, and words or names which he regarded as important, presumably when he reread the diary later.

Lajos György was placed in the Laznica camp, which was, relatively speaking, the best in Bor. It was the only subcamp of Bor that was situated inside a village and was not surrounded by a fence due to its location. It was the furthest Hungarian subcamp from Bor and it was not along the busier north-south main road. Last but not least, the commander of the camp, ensign Jenő Halász, had a comparatively humane attitude. ${ }^{49}$ Yet later, Lajos György encountered a member

\footnotetext{
48 A total of 13 drawings including signatures in two places. There are also three words and remarks written in the margins in the same red ink ("гладам сам" [I am hungry], "B.U.É.K." (the Hungarian abbreviation for Happy New Year), and "Hungária").

49 Reserve ensign Dr. Jenő Halász was a teacher in Újvidék (Novi Sad). Two pieces of news spread about him among the forced laborers (he fled and joined the partisans, and he did not return after his official time off). He was sentenced to five years of imprisonment in Yugoslavia after 1945. The second commander of the camp was lieutenant Béla Nagy from Szeged.
} 
of the detachment named János Császár in the Berlin camp. ${ }^{50}$ The cruelty of this sergeant major had the same negative effect on him as it did on the other diarists. Later, like László Faludi, György Laufer, and György Szöllösi, Lajos György also participated in the people’s tribunal trial of János Császár. ${ }^{51}$

\section{Summary}

On the basis of the number of diaries which have survived, even if in some cases only in fragments, one has the impression that very few of the forced labor service men in Bor wrote diaries. Two of the authors of the surviving six diaries were taken to the Berlin camp with the 1943 group and spent 14 months in Bor. The others arrived a year later and were held captive in different subcamps in the mountains. The diaries clearly show how differently the diarists experienced their forced labor service, depending on their ages, qualifications, assignments, and the conditions in the camps. Nothing was previously known about how a forced laborer lived and thought during his time in Bor if he worked inside the camp, for instance in the kitchen, or he was a photographer or a clerk or if he had been in the organized labor movement. The Bor diaries provide us with a few impressions of the experiences of forced labor in theaters of military operations or under Hungarian and German control. Notes made in the present tense at the locations and the later transcripts make it possible to draw a more nuanced picture.

Another perspective from which the diaries may offer a more nuanced understanding of the experiences of people assigned to forced labor camp service involves the so-called "Jewish question" in the camp. As György Laufer writes in his diary (which is the only source known so far which touches on this), the Jewish forced laborers were marked with "the Mogen Dovid," which was daubed in "oil paint" on their chests and their backs (Laufer writes about this in the entry from March 30, 1944). ${ }^{52}$ So from then on, the Hungarian Jewish forced laborers held as prisoners in the Berlin camp were compelled to wear the

50 János Császár (mother’s name Judit Burkus; Medgyesegyháza, April 17, 1905-Szeged, August 3, 1945) was a sergeant major and a member of the detachment in the Bregenz and Rhön subcamps and then in the Berlin camp. The Szeged people's tribunal sentenced Császár to death for war crimes in 1945 and he was executed.

51 BFL Nb.206/1945. 160-61. Lajos György's handwritten, signed submission without any date. The registered date is June 19, 1945. János Császár's trial at the people’s tribunal. No. of acknowledgment of receipt: 1542/1945.

52 Diary, March 30, 1944. Mogen Dovid: Star of David, in Hebrew Magen David. 
Star of David on their clothing until the liberation. Béla Somló dealt most with the situation of the Jews in the camp. He was preoccupied with the difference between the position of "whites" and "yellows" (the term "white" referred to people who were born Jewish but converted to the Christian faith. They were officially considered Jews). He often wrote about the distinction between "white" Jews and non-baptized "yellow" Jews. Thus the anti-Jewish laws carried weight in acts of discrimination even in Bor. Those with yellow armbands could not be cooks, nor could they work in the kitchen. Moreover, they could not be workers within the camp or be present in the office. They had to turn in their boots and wear the Star of David. Béla Somló, Imre Pártos, and Lajos György had white arm bands, as did the poet Miklós Radnóti and the philosopher Sándor Szalai, who were also taken to Bor.

With one exception, the Bor diaries did not end in Bor. They record the liberation and the experience of encountering the partisans and Russian soldiers. They also describe what the forced laborers experienced during their escape, on the way home, and at the locations where they stayed. After having survived Hungarian and German captivity, they were still exposed to threats from the partisans and the looming danger of falling into Russian captivity. The diaries show precisely how the war, its consequences, and the temporary situations affected them. Arrival home also presented them with losses, since they learned that many of their relatives had perished in the Holocaust. They had to rethink their lives, including their personal lives. In different ways, they participated in the emergence of a new world, including the rise of a different dictatorship, the complex circumstances of which they themselves struggled with later. ${ }^{53}$

\section{Bibliograpby}

Primary sources

Állambiztonsági Szolgálatok Történeti Levéltára [Historical Archives of the Hungarian State Security] (ÁBTL)

Béla, Somló. 3.1.5. O-9054.

Budapest Fôváros Levéltára [Budapest City Archives] (BFL)

Nb.206/1945. 160-161. Lajos György

Nb.3281/1945.80. András Tálas

53 I would like to thank everyone in the public collections and private archives who helped me in my work, as well as those who contributed to the process of creating accurate typewritten versions of the diaries. 
XXV.1.a. 3757-1947, Károly Peyer

XXV.2.b. 13981-1945, Mihály Kolosváry-Borcsa

Holocaust Emlékközpont [Holocaust Memorial Center]

Károly, Koltai. 2011.360.1.

Honvédelmi Minisztérium Hadtörténeti Intézet és Múzezum [Ministry of Defence

Military History Institute and Museum Military History Archives] (HM HIM HL)

PGy 2826. Béla, Somló. Diary. The participation of the Pécs motorised heavy vehicle division IV/2 in entering the region to the south of Hungary's border in 1941 (1980)

PgyM/368 and M/368. Béla, Somló. Diary (Bor, 1 June 1944-Temesvár, 19 October 1944). Diary (Temesvár, 19 October 1944-Budapest, 27 February 1945).

TGy 2811. Béla, Somló. Diary. The participation of the column of the Pécs motorised vehicle division IV/2 in the rapid deployment force of the military campaign in Russia (1941).

Hadisír Nyilvántartó [Records of Military Graves], http://www.hadisir.hu/hadisirnyilvantarto

Magyar Nemzeti Levéltár Csongrád-Csanád Megyei Levéltára [National Archives of Hungary Csongrád and Csanád County Archives] (MNL CSML)

Szeged Nb.206/1945. Trial of cadet sergeant János Császár

Szeged, Nb.1106/1945. Lance corporal Mihály Palócz's war crime

Szeged, Nb.1200/1945. Captain István Vida’s anti-people crime.

Magyar Nemzeti Múzeum [Hungarian National Museum] (MNM)

Legújabb Kori Iratgyújtemény [Collection of Contemporary Documents]

83.242.1. Faludi, László. Diary of a Bor forced laborer

Történeti Fényképtár [Department of Historical Photographs]

78.386. Faludi, László. Three camp postcards

Magyar Zsidó Múzeum és Levéltár [Hungarian Jewish Museum and Archives]

B/327 L2_E4_75. Laufer, György. Diary written during Bor forced labor service

Visual History Archive (VHA)

USC, Shoah Foundation, George Brent, interview 19753, 1996.

György, Lajos. Diary. 31 May 1944-1 April 1945. The original copy of the diary is with

Lajos György's widow, Otilia Vass (Budapest), while the copy seen by me is in Péter György's ownership.

Magyar Közlöny [Hungarian Official Gazette], 124.12.1954, no. 106, 754.

Magyar Közlöny [Hungarian Official Gazette], 16.02.1950, no. 28, 1.

Nemzeti Emlékezet Bizottsága [Committee of National Remembrance] (NEB)

Datebase. https://perek56.hu/ords/f?p=1051:1 
Pártos, Imre. Diary. The original diary and Imre Pártos's documents connected to his forced labor service in Bor are in the ownership of his daughter-in-law and granddaughter (Budapest).

Somló, Béla. Diary (Bor, 1 June 1944-Temesvár, 19 October 1944). Diary (Temesvár, 19 October 1944-Budapest, 27 February 1945). The originals are owned by Márta Koczka Sántháné (Debrecen).

Szöllösi, György. Diary. The original copy of the diary is owned by Dennis Brent (Dallas).

Secondary literature

Anonymous. "Itt a feketézők, valutázók, árdrágítók második hivatalos listája" [The second official list of black marketeers, illegal dealers in foreign currencies, and profiteers]. Világosság, March 3, 1946.

Csapody, Tamás. "Laufer György naplója” [György Laufer's diary]. Múltunk 64, no. 1 (2019): 184-224.

Csapody, Tamás. "A naplóíró Somló Béla" [The diary writer is Béla Somló]. FONS 24, no. 3 (2019): 339-402.

Gyáni, Gábor. "A napló mint társadalomtörténeti forrás: A közhivatalnok identitása" [The diary as a social history source: The identity of a public servant]. In Gyáni, Gábor, Emlékezzés, emlékezzet és a történelem elbeszélése [Remembrance, memory and the narration of history], 145-60. Budapest: Napvilág Press, 2000.

György, Péter. "Az amnézia-terápia: A Kádár-korszak fausti egyezsége" [Therapy of amnesia: The Faustian pact of the Kádár era]. Alföld 61, no. 1 (2010): 64-69.

György, Péter. Apám helyett [Instead of my father]. Budapest: Magvető Press, 2011.

Kunt, Gergely. Kamasztükör: A hosszú negyvenes évek társadalmi képzetei fiatalok naplóiban [Reflections of adolescents: Social ideas of the long 1940s in diaries of young people]. Budapest: Korall Press, 2017.

Sinclair Jr., Upton Beall. Kutató Sámuel [Samuel the Seeker]. Translated by Dezső Schöner. Budapest: Népszava, 1913. 